\title{
APLIKASI PEMBELAJARAN TEKNIK DASAR FUTSAL MENGGUNAKAN AUGMENTED REALITY BERBASIS ANDROID
}

\author{
Sanriomi Sintaro'), Ade Surahman ${ }^{2)}$, Nofri Khairandi ${ }^{3)}$ \\ ${ }^{1,2,3}$ Informatika, Fakultas Teknik dan Ilmu Komputer, Universitas Teknokrat Indonesia \\ 1,2,3 Jl. Z.A Pagaralam, No 9-11, Labuhan Ratu, Bandarlampung \\ Email: ${ }^{1}$ sanriomi@teknokrat.ac.id, ${ }^{2}$ adesurahman@teknokrat.ac.id, ${ }^{3}$ nofrikhairandi@gmail.com
}

\begin{abstract}
Abstrak
Futsal merupakan salah satu cabang olahraga yang termasuk dalam permainan bola besar. Seorang pemain futsal harus mampu memahami dan menguasai teknikteknik dasar dalam permainan futsal agar kerja sama tim dapat terbentuk dengan baik. Dalam proses latihan futsal saat ini masih menggunakan buku yang dimiliki pelatih sebagai acuan dalam berlatih futsal khususnya teknik dasar futsal. Jadwal latihan yang sedikit, penyampaian teori dan praktik tentang teknik dasar futsal tidak dapat diberikan secara maksimal karena keterbatasan waktu serta banyaknya anggota yang ingin berlatih teknik dasar futsal menjadi kendala tersendiri bagi pelatih dalam penyampaian materi terutama bagi anggota baru. Maka dirancang sebuah aplikasi yang dapat menerangkan tentang teknik dasar futsal dengan memanfaatkan teknologi Augmented Reality yang dibuat menggunakan Unity $3 D$ dan Vuforia SDK. Aplikasi pembelajaran teknik dasar futsal dibuat dalam bentuk visualisasi animasi $3 D$ berbasis Android, dengan tujuan sebagai alat peraga dari teori yang ada dan pemain dapat belajar tanpa harus dicontohkan oleh pelatih secara langsung. Berdasarkan hasil pengujian menggunakan blackbox menunjukan bahwa aplikasi yang dibangun sudah memenuhi persyaratan fungsional. Dari hasil pengujian beta yang telah dilakukan dengan menggunakan metode penerimaan kepada para responden menghasilkan nilai sebesar $83 \%$ responden tertarik menggunakan Aplikasi Pembelajaran Teknik Dasar Futsal AR 3D.
\end{abstract}

Kata Kunci: Aplikasi Pembelajaran, Futsal, Augmented Reality, 3D, Android

\section{Pendahuluan}

Futsal merupakan salah satu cabang olahraga yang termasuk dalam permainan bola besar. Futsal, dewasa ini berkembang menjadi salah satu permainan alternatif sepak bola, menilik pada efisiensi penggunaan lahan atau lapangan bermain yang lebih kecil. Oleh karena itu futsal dianggap sebagai permainan yang mampu memberikan sensasi bermain yang sama halnya didapat oleh pemain saat bermain sepak bola. Bermain futsal pada dewasa ini sudah dianggap sebagai gaya hidup, terutama di kotakota besar. Semua kalangan umumnya bisa memainkannya, terutama kalangan remaja dan mahasiswa. Hal tersebut didukung oleh beragam fasilitas lapangan futsal yang menjamur di setiap kota dan menjadikan olahraga ini salah satu olahraga paling banyak diminati oleh masyarakat [1].

Smartphone menjadi kebutuhan sehari-hari setiap orang, kenyamanan penggunaan sistem operasi Android membuat penggunanya cukup tinggi [2]. Pengguna dapat mengunduh berbagai aplikasi dengan mudah, lebih dari 700.000 aplikasi tersedia di google play [3]. Selain itu Android juga dapat menampilkan gambar 2D dan 3D atau bahkan gabungan objek 2D dan 3D di dunia nyata secara real time [4].

Media pembelajaran ternyata selalu mengikuti perkembangan teknologi yang ada, mulai dari teknologi cetak, audio visual, komputer sampai teknologi gabungan antara teknologi cetak dengan komputer. Saat ini media pembelajaran hasil gabungan teknologi cetak dan komputer dapat diwujudkan dengan teknologi Augmented Reality (AR). Teknologi Augmented Reality (AR) atau dapat disebut juga sebagai realitas tertambah merupakan integrasi elemen digital yang ditambahkan ke dalam dunia nyata secara waktu nyata (data real-world) dan mengikuti keadaan lingkungan yang ada di dunia nyata serta dapat diterapkan pada perangkat mobile [5].

Seorang pemain futsal harus mampu memahami dan menguasai teknik-teknik dasar dalam permainan futsal. Teknik dasar permainan futsal bisa menjadi kemampuan awal bagi pemain futsal. Kemampuan dasar ini harus dilatih dan diasah oleh pemain untuk menemukan pola permainannya sendiri dan skill individunya yang saat diaplikasikan bersama tim akan berguna [1]. Dengan menerapkan teknologi Augmented Reality berbasis Android, diharapkan informasi yang disajikan dapat terlihat menarik dan informatif serta dapat mempermudah pengguna dalam mendapatkan informasi secara langsung. Kebutuhan akan suatu informasi yang dibutuhkan bagi pengguna dengan tingkat mobilitas tinggi membuat mobile phone tidak hanya sebagai alat komunikasi namun juga sebagai alat untuk mendapatkan suatu informasi [6].

Dengan memanfaatkan smartphone yang menjadi kebutuhan sehari-hari setiap orang, kenyamanan penggunaan sistem operasi Android membuat penggunanya cukup tinggi. Dalam hal tersebut maka penulis melakukan penelitian untuk merancang dan membangun aplikasi pembelajaran teknik dasar futsal untuk pemain futsal yang menarik, interaktif dan mampu 
memberikan pengetahuan tentang teknik dasar futsal yang memanfaatkan teknologi Augmented Reality berbasis Android dengan menampilkan simulasi objek 3D yang diinginkan dapat membantu pelatih dalam memberikan latihan teknik dasar futsal kepada pemain.

\section{Landasan Teori}

\section{A. Aplikasi Pembelajaran}

Aplikasi pembelajaran adalah suatu program yang mengemas sebuah metode pembelajaran berbantuan komputer yang dapat memberikan respon balik terhadap pengguna akhir dari apa yang telah diinputkan kepada aplikasi tersebut [7].

\section{B. Multimedia}

Multimedia adalah kombinasi dari penggunaan beberapa media seperti film, slide, musik, penerangan dengan text, image, khususnya untuk tujuan pendidikan, dan hiburan. Unsur-unsur seperti teks, audio (narasi, dialog, sound effect), musik, film, video, fotografi, animasi dan grafik merupakan media pendukung yang tergantung dan terintegrasi menjadi satu-kesatuan karya multimedia. Bentuk Interaktif Multimedia termasuk didalamnya WebSite, CDRom Interactive, Program/software, Presentasi, Tutorial, Help section, dan bahkan Games [8].

\section{Futsal}

Menurut [1] Futsal merupakan salah satu cabang olahraga yang termasuk dalam permainan bola besar. Futsal, dewasa ini berkembang menjadi salah satu permainan alternatif sepak bola, menilik pada efisiensi penggunaan lahan atau lapangan bermain yang lebih kecil. Oleh karena itu, futsal dianggap sebagai permainan yang mampu memberikan sensasi bermain yang sama halnya didapat oleh pemain saat bermain sepak bola. Bermain futsal pada dewasa ini sudah dianggap sebagai gaya hidup, terutama di kota-kota besar. Semua kalangan umumnya bisa memainkannya, terutama kalangan remaja dan mahasiswa. Hal tersebut didukung oleh beragam fasilitas lapangan futsal yang menjamur di setiap kota, dan menjadikan olahraga ini salah satu olahraga paling banyak diminati oleh masyarakat[1].

Seorang pemain futsal harus mampu memahami dan menguasai teknik-teknik dasar dalam permainan futsal. Teknik dasar permainan futsal bisa menjadi kemampuan awal bagi pemain futsal. Kemampuan dasar ini harus dilatih dan diasah oleh pemain untuk menemukan pola permainannya sendiri dan skill individunya yang saat diaplikasikan bersama tim akan berguna. Berikut teknikteknik dasar yang harus dikuasai oleh pemain futsal:

\section{Teknik Dasar Mengumpan (Passing)}

Bagi pemula, passing bisa dilakukan dengan kaki bagian dalam. Baik pemain yang menggunakan kaki kiri atau kaki kanan, teknik passing menggunakan kaki bagian dalam sama saja dalam penerapan. Mula-mula pemain akan berdiri di belakang bola, lalu kaki yang digunakan untuk menendang dibengkokkan sehingga bagian dalam kaki berhadapan dengan bola. Lalu tendang bola menggunakan kaki bagian dalam tersebut ke arah pemain yang diinginkan.

\section{Teknik Dasar Menahan Bola (Control)}

Untuk mengontrol bola menggunakan kaki bagian dalam, tekniknya sama dengan passing yang di atas. Kaki dibengkokkan sehingga bagian dalam kaki menghadap arah datangnya bola. Ketika bola bersentuhan dengan kaki bagian dalam tersebut, jangan berikan tekanan pada bola, kaki rileks saja, lalu kemudian bola bisa diumpan ke pemainlain atau digiring ke arah lainnya.

\section{Teknik Dasar Mengumpan Lambung (Chipping)}

Chipping biasanya diterapkan oleh suatu tim yang mengusung strategi long-ball atau bola panjang. Strategi ini dilakukan ketika tim melakukan serangan balik langsung ke daerah pertahanan lawan.

Chipping umumnya dilakukan dengan kaki bagian luar atau punggung kaki tekniknya sama dengan saat melakukan passing. Hanya saja, ketika menendang bola ada sedikit pergerakan kaki yang mengupayakan bola terangkat. Hal ini dikarenakan ada titik bola yang ditendang bersentuhan dengan pangkal jempol kaki. Teknik ini butuh latihan yang banyak untuk menguasainya. Atau, bagi yang belum mampu, chipping bisa dilakukan dengan ujung kaki. Akan tetapi, hal ini membuat pergerakan bola lambung menjadi sangat cepat dan susah untuk diterima kawan bermain kita.

\section{Teknik Dasar Menggiring Bola (Dribling)}

Dapat dilakukan dengan bagian kaki luar, kaki dalam, serta punggung kaki. Dribling menggunakan kaki bagian luar atau punggung kaki biasanya lebih mudah dari pada dribling menggunakan kaki bagian dalam. Posisi bola melekat pada bagian kaki yang digunakan untuk menggiring bola. Jika pun diberi jarak, maka jarak dengan kaki kita saat melakukan dribling tidak boleh lebih dari 1 meter. Jarak idealnya adalah 30 sampai 50 cm saja.

\section{Teknik Dasar Menembak (Shooting)}

Dalam melakukan shooting, yang pertama sekali harus ditentukan adalah ke mana arah bola yang akan ditentang. Shooting umumnya dilakukan untuk menciptakan gol. Namun adakalanya shooting dilakukan bertujuan untuk membuang bola sejauh mungkin dari daerah pertahanan sendiri.

Pada teknik shooting menggunakan punggung kaki, posisi pandangan kita mengarah pada bola. Posisi lutut di atas bola, tekuk jari kaki Anda ke bawah saat sedang menendang. Tendang bagian tengah bola dengan punggung kaki sambil tetap menundukan kepala. Ikuti dengan ayunan kaki supaya tendangan Anda bertenaga sehingga bola terlontar jauh. Gunakan kedua lengan anda untuk menjaga keseimbangan agar bola bisa melayang sesuai keinginan Anda. 


\section{Tendangan dengan Ujung Kaki}

Dalam permainan futsal, shooting dilakukan dengan keras dan sekuat tenaga. Penggunaan tenaga kaki yang besar saat melakukan tendangan karena dalam permainan futsal jarak pemain saling berdekatan. Selain itu, untuk memecah konsentrasi penumpukan pemain dalam sebuah wilayah maka tendangan keras menjadi opsi yang cukup baik dilakukan. Dalam sepak bola, tendangan yang menggunakan ujung kaki atau ujung sepatu tidak biasa dilakukan, apalagi oleh pemain-pemain dunia. Namun dalam permainan futsal, sepakan menggunakan ujung kaki atau ujung sepatu sering dilakukan karena kekuatan tendangan bisa lebih besar dari pada melakukan tendangan menggunakan kaki bagian dalam, kaki bagian luar, maupun punggung kaki.

\section{Teknik Menyundul Bola (Heading)}

Heading adalah cara untuk menguasai bola dengan menggunakan kepala. Heading diantaranya dilakukan sebagai umpan kepada rekan setim dan untuk mencetak gol pada saat posisi memungkinkan mencetal gol lewat kepala. Bagian kepala yang digunakan untuk melakukan heading adalah kening. Namun, ada pemain yang belum mahir melakukan heading menggunakan bagian atas kepala. Bagian ini sebenarnya cukup berbahaya, apalagi saat bola datang dengan laju yang cepat. Supaya aman, heading harus dilakukan dengan kening. Dan, pada prosesnya tenaga dalam melakukan heading berasal dari otot leher.

\section{Teknik Membendung Bola}

Dalam suatu permainan futsal, membendung bola hasil shooting pemain lawan dapat dilakukan dengan cara $\mathrm{M}$ position atau $\mathrm{L}$ position. Posisi ini merujuk pada posisi kaki saat melakukan pembendungan bola. Untuk M position, kaki membentuk huruf $\mathrm{M}$ dengan kedua lutut saling bersentuhan menyentuh permukaan tanah. Posisi paha rapat dan kedua tangan bersiap di kedua sisi paha tersebut. Sedangkan untuk L position, kaki berbentuk huruf L dengan salah satu lutut menyentuh permukaan tanah. Sedangkan kaki satunya lagi mengikuti arah vertikal dari posisi lutut tadi.

\section{Teknik Melempar Bola}

Melempar bola atau throw merupakan teknik yang harus dimiliki oleh seorang penjaga gawang. Teknik dalam melakukan lemparan adalah dengan cara kepala lurus tegak, penjaga gawang harus meletakan bola pada jari dan telapak tangan dimana lengan lurus dibelakang. Posisi sudut badan mengarah ke target sasaran, bagian tangan yang akan melempar bola lurus di belakang. Posisi tangan yang berlawanan lurus ke arah sasaran. Lengkungkan tubuh atas bagian belakang yang ditumpukan pada pinggang lalu lemparkan bola. Setelah bola dilempar, gerakan kaki yang belakang berpindah posisi ke depan untuk menjaga keseimbangan.

\section{Android}

Android adalah sebuah sistem operasi berbasis Linux yang digunakan untuk perangkat mobile seperti telepon pintar (smartphone) dan komputer tablet. Android mencakup sistem operasi, middleware, dan aplikasi yang menyediakan platform terbuka untuk bagi para pengembang untuk menciptakan aplikasi mereka. Android didirikan tahun 2003 di California oleh Andy Rubin (pendiri Danger), Rich Miner (pendiri Wildfire Communications,Inc.), Nick Sears dan Christ White (kepala desain dan pengembangan antarmuka WebTV).

Tujuan awal pengembangan android yaitu mengembangkan sebuah sistem operasi yang canggih dan diperuntukkan bagi kamera digital, namun disadari bahwa pasar untuk perangkat itu tidak cukup besar. Pengembangan Android dialihkan bagi pasar smartphone [9].

\section{E. Augmented Reality}

Augmented Reality merupakan sebuah terobosan dan inovasi baru bidang multimedia dan image processing yang sedang berkembang. Teknologi ini mampu mengangkat sebuah benda yang sebelumnya datar atau dua dimensi, seolah-olah menjadi nyata, bersatu dengan lingkungan sekitarnya [10].

Teknologi Augmented Reality yang merupakan pengembangan dari Virtual Reality memiliki konsep yang berbeda. Ketika Virtual Reality menarik pengguna seakan masuk ke dalam lingkungan 3 dimensi, maka Augmented Reality menambahkan realita yang ada dan nyata di dunia kita dengan objek yang terangkat (Augmented), dimana teknologi ini seakan menghilangkan dunia maya 3 dimensi, menyatu dengan dunia nyata.

Terdapat empat komponen yang harus diperhatikan dalam hal pengembangan dan penggunaan Augmented Reality [10], yaitu:

1. Perangkat Keras

2. Perangkat Lunak

3. Alat Pengindaian

4. Marker

Komponen pertama adalah perangkat keras, perangkat keras yang dapat digunakan berupa PC, laptop, smartphone, maupun tablet. PC dan laptop digunakan sebagai alat pengembangan aplikasi, sedangkan smartphone dan tablet digunakan sebagai dasar tempat aplikasi akan ditanamkan atau diinstal.

Komponen kedua adalah perangkat lunak hasil pengembangan yang telah dilakukan di sebuah software pembentuk aplikasi Augmented Reality. Platform dari aplikasi saat ini dapat dijalankan pada platform PC, Android, dan IOS. Komponen ketiga adalah alat pengindai atau scanner untuk melakukan pengindaian pola dan mengaktifkan Augmented Reality. Alat yang dapat digunakan sebagai alat pengindaian berupa webcam untuk PC maupun kamera yang sudah tersedia pada smartphone maupun tablet.Komponen terakhir adalah marker sebagai lokasi titik kemunculan dari objek Augmented Reality. Pengembangan dari marker sendiri memerlukan teknik pembentuk pola. Pola dapat berupa hitam putih atau non-pola. Setiap pola akan terlebih dahulu diuji seberapa kompatibel dan layak untuk digunakan sebagai marker dengan software khusus [10]. 


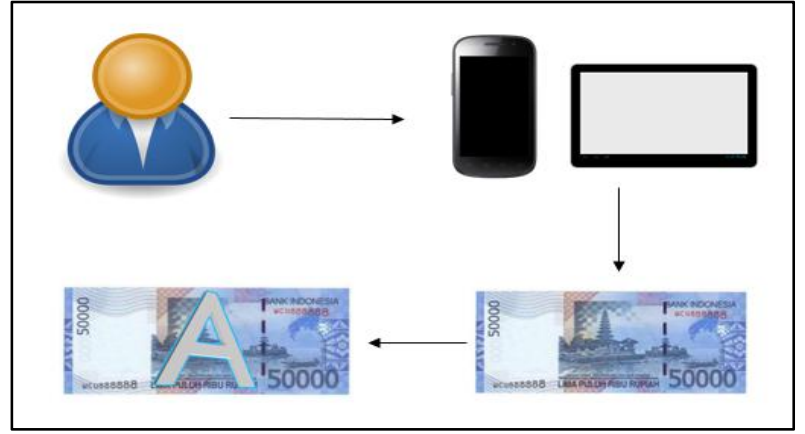

Gambar 2.1 Ilustrasi Cara Kerja Augmented Reality

Dalam Sujati, dkk., (2016) Yudiantika menyatakan bahwa, alur kerja aplikasi AR secara umum dimulai dari pengambilan gambar marker dengan kamera atau webcam. Marker tersebut dikenali berdasarkan feature yang dimiliki. kemudian masuk kedalam object tracker yang disediakan oleh Software Development Kit (SDK). Disisi lain, Marker telah didaftarkan dan disimpan ke dalam database. Object tracker selanjutnya akan melacak dan mencocokan marker tersebut agar dapat menampilkan informasi yang sesuai. Hasil keluaran pelacakan marker akan ditampilkan pada layar komputer dan layar ponsel cerdas. Informasi yang ditampilkan melekat pada marker bersangkutan secara real time [11].

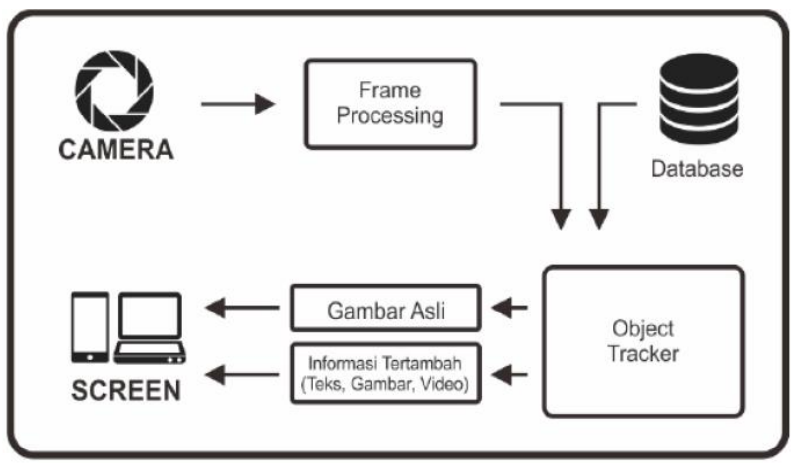

Gambar 2.2 Alur Kerja Augmented Reality

\section{F. Unity $3 D$}

Unity $3 D$ merupakan sebuah platform pengembangan game 2 dimensi maupun 3 dimensi yang dapat digunakan oleh pengembang baru maupun pengembang yang sudah berpengalaman. Javascript dan C\# merupakan bahasa pemrograman yang dipakai dalam pengembangannya, kemudahan keterhubungan antara objek yang sedang dikembangkan dan script pemrograman menjadikan pilihan yang baik bagi pengembang yang memiliki keterbatasan waktu namun memiliki segudang ide [10].

\section{G. Vuforia $S D K$}

Vuforia merupakan sebuah Software Development Kit SDK yang dikeluarkan oleh Qualcomm, untuk pengembangan aplikasi dibidang computer vision, khususnya teknologi Virtual Reality dan Augmented Reality. Teknologi yang diusung oleh Qualcomm sebagai pengembang adalah dari sisi pembuatan target, penempatan target marker, dan konfigurasi SDK dasar dari teknologi Augmented Reality [10].

\section{H. Marker}

Marker adalah sebuah penanda yang didalamnya terdiri dari kumpulan titik acuan untuk memudahkan komputasi dari pengukuran parameter- parameter yang dibutuhkan dalam pembuatan Augmented Reality. Marker dapat berupa warna atau gambar, marker yang paling sederhana adalah marker matrix. Marker matrix menggunakan 2D barcode sederhana yang dipakai untuk mengenali sebuah objek dan untuk mengetahui hubungan antara posisi kamera dengan penanda tersebut. Ukuran standar marker adalah 631 x 634 pixel [12].
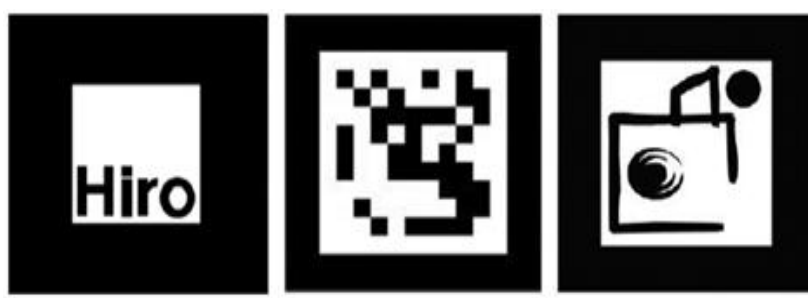

Gambar 2.3 Pola Marker

\section{Blender}

Blender adalah aplikasi grafik komputer yang memungkinkan anda untuk memproduksi gambar dan animasi berkualitas tinggi dengan menggunakan geometri tiga dimensi [13].

\section{J. Makehuman}

MakeHuman merupakan salah satu software yang digunakan untuk membuat karakter 3 dimensi dimana karakter tersebut tampak realistis seperti manusia [13].

\section{K. Adobe Photoshop CS}

Adobe Photoshop CS secara umum dikenal sebagai alat untuk memanipulasi image dan bukan alat untuk membuat dan menciptakan image. Namun demikian, photoshop memiliki kemampuan untuk menjadi program melukis disamping sebagai pengedit image [14].

\section{Metode Pengembangan Sistem}

Metode pengembangan sistem yang digunakan pada penelitian ini adalah metodologi Multimedia Development Life Cycle (MDLC). Dalam (Hidayat dan Mujahiduddien, 2017) [15], Menurut Sutopo yang memodifikasi method Luther, berpendapat bahwa metode pengembangan perangkat lunak multimedia terdiri atas 6 tahapan, yaitu concept, design, material collecting, assembly, testing, dan distribution [16]. 


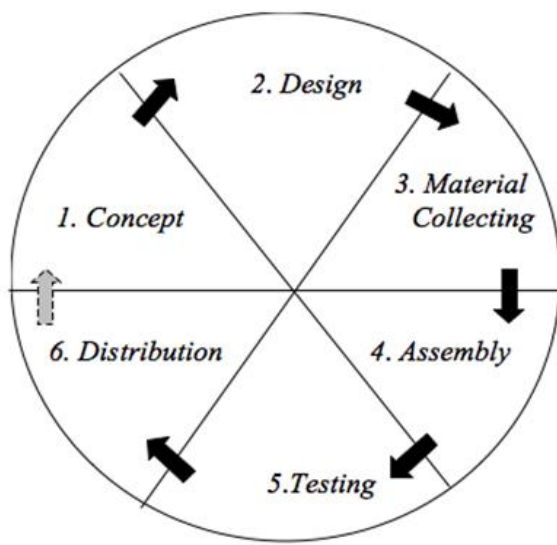

1. Concept

Tahapan ini menentukan tujuan dan siapa pengguna program (identifikasi audience). Selain itu menentukan macam aplikasi dan tujuan aplikasi.

\section{Design}

Tahap membuat spesifikasi mengenai arsitektur program, gaya, tampilan, dan kebutuhan material/bahan untuk program.

\section{Material Collecting}

Tahap dimana pengumpulan bahan yang sesuai dengan kebutuhan dilakukan. Tahap ini dapat dikerjakan secara paralel dengan tahap assembly.

\section{Assembly}

Tahap dimana semua objek atau bahan multimedia dibuat. Pembuatan aplikasi didasarkan pada tahap design.

\section{Testing}

Tahap ini dilakukan setelah menyelesaikan tahap assembly dengan menjalankan aplikasi dan dilihat apakah terjadi kesalahan atau tidak. Tahap ini disebut juga tahap pengujian.

\section{Distribution}

Tahap dimana aplikasi disimpan dalam suatu media penyimpanan. Pada tahap ini jika media penyimpanan tidak cukup untuk menampung aplikasi tersebut, dilakukan kompresi terhadap aplikasi tersebut.

\section{Hasil dan Pembahasan}

A. Rancangan Sistem

1. Struktur Navigasi

Perancangan struktur navigasi yang menggambarkan hubungan antar menu pada penelitian ini menggunakan model hirarki.

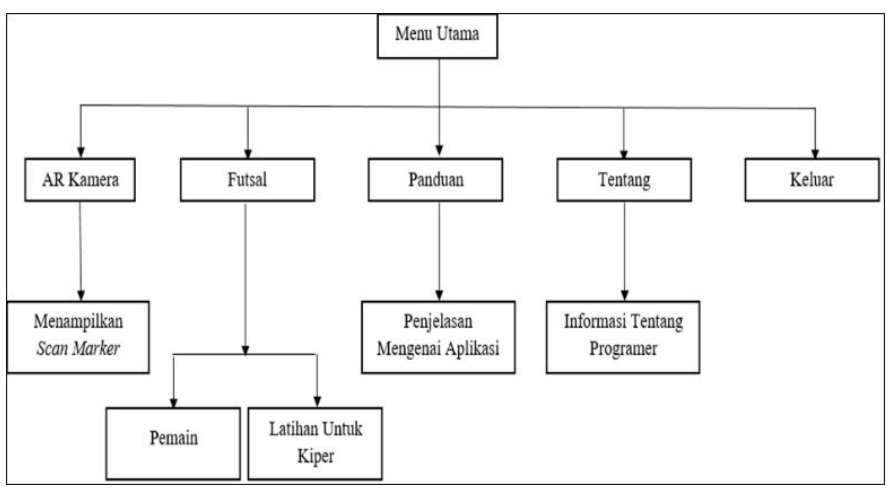

\section{Flowchart View}

Flowchart view menggambarkan alur dari satu tampilan ketampilan lainnya. Berikut flowchart view.

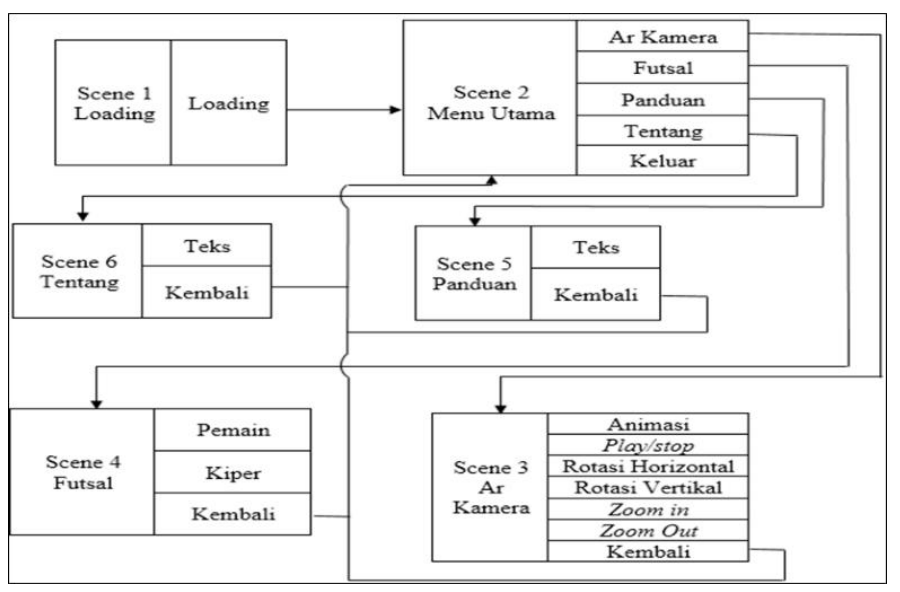

\section{B. Implementasi}

1. Splash Screen Loading

Pada halaman Splash Screen Loading menampilkan logo aplikasi pembelajaran "Teknik Dasar Futsal" dan Loading Bar. Tampilan Splash Screen Loading dapat dilihat pada Gambar 1.

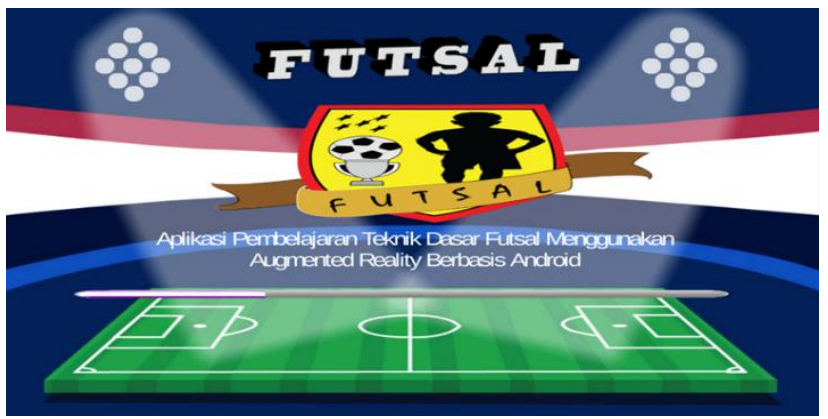

Gambar 4 Tampilan Splash Screen Loading

2. Menu Utama

Menu Utama merupakan sebuah halaman yang berisi menu-menu yang nantinya akan dipilih oleh pengguna, halaman tersebut berisi Ar Kamera, Futsal, Panduan, dan Tentang. Hasil implementasi menu utama dapat dilihat pada Gambar 2. 


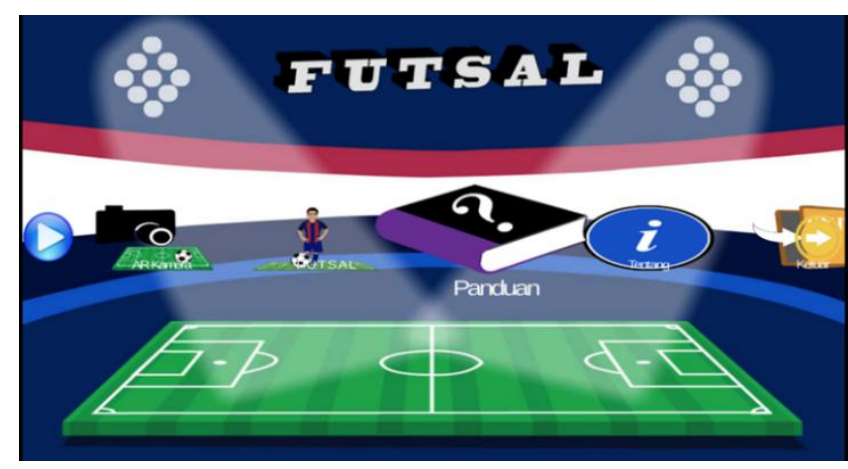

Gambar 5 Tampilan Menu Utama

\section{AR Kamera}

AR Kamera merpakan menu yang akan tampil ketika tombol menu ar kamera dipilih. Pada menu tersebut berisi tombol kontrol animasi teknik dasar futsal apabila telah scan marker, terdapat tombol play/stop, rotasi, zoom in/out dan panel deskripsi gerakan. Hasil implementasi menu Ar Kamera dapat dilihat pada Gambar 3.

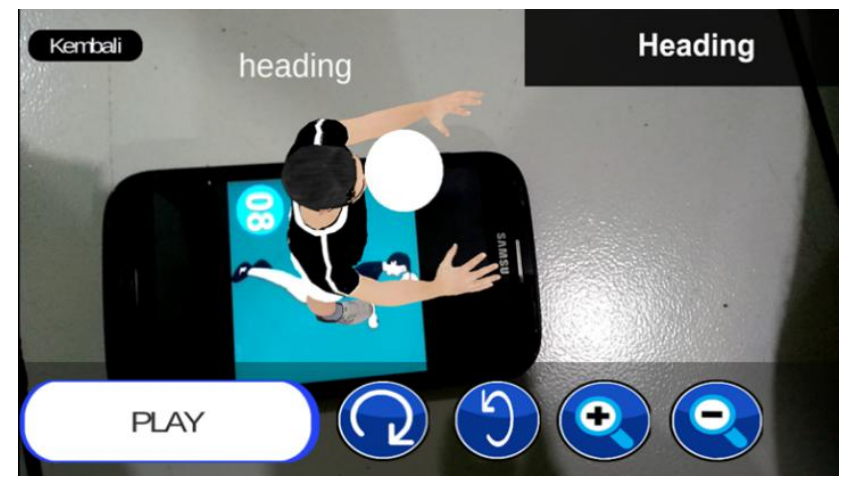

Gambar 6 Tampilan Ar Kamera

\section{Menu Futsal}

Menu Futsal merupakan sebuah halaman yang berisikan materi dari Teknik Dasar Futsal, serta terdapat tombol back, next, kembali, dan scroll materi. Hasil implementasi Menu Futsal dapat dilihat pada Gambar 4.

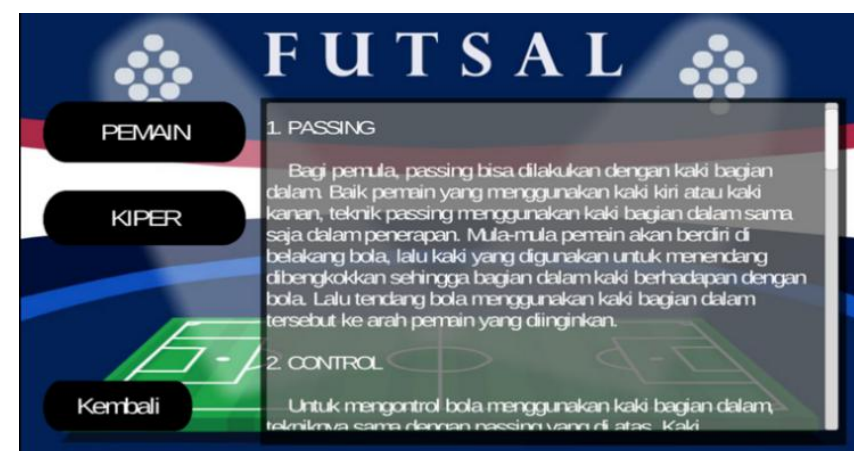

Gambar 7 Tampilan Menu Futsal

\section{Panduan}

Menu Panduan merupakan sebuah menu yang berisi petunjuk penggunaan aplikasi, yaitu petunjuk bagaimana cara untuk memilih menu pada menu utama dan petunjuk untuk menjelaskan tombol apa saja yang terdapat pada ar

kamera, pada menu ini juga disertai tombol back untuk kembali ke menu sebelumnya, serta tombol Kembali ke menu utama, next, dan di sertai animasi. Hasil implementasi menu Panduan dapat dilihat pada Gambar 5.

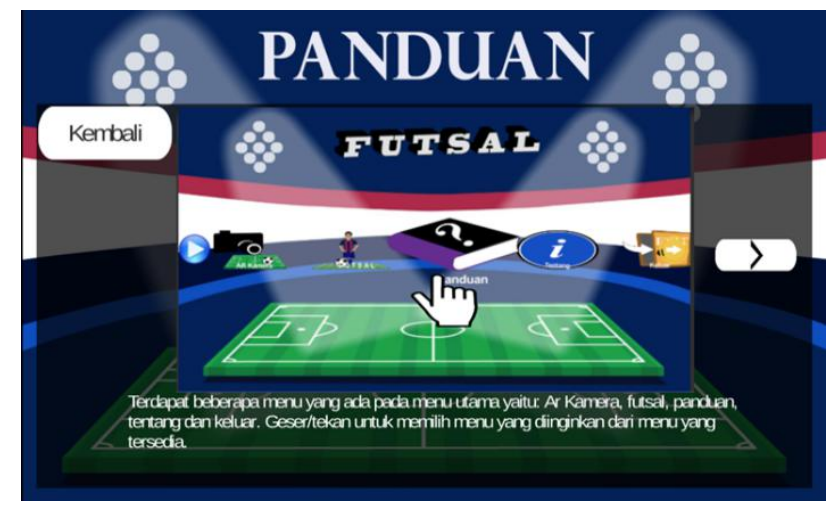

Gambar 8 Tampilan Menu Panduan

6. ARBook

ARBook adalah sebuah buku yang didalamnya berisikan materi pengenalan futsal, sejarah futsal, peraturan futsal dan materi tentang teknik dasar futsal. Dimana pada bagian teknik dasar futsal terdapat marker yang dapat dipindai untuk memunculkan simulasi 3D sebagai peraga dari teori yang ada. Hasil implementasi ARBook dapat dilihat pada Gambar 7.

\section{BUtरण

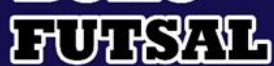

\section{ARBOOR}

Pada buku ini berisi tentang:

Pengenalan Futsal

Sejarah Futsal
Peraturan Futsal

Peraturan Futsal
Teknik Dasar Futsal

Untuk Teknik Dasar Futsal memiliki

pada tiap-tiap materi yang fungsiny

menampilkan 3D animasi tentang materi yang dipelajari dangan menscan marker yang tersedia.
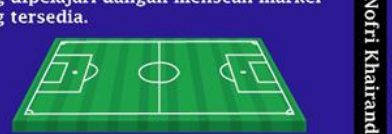

\section{BUसD FU나매재}

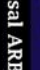
Nofri Khairandi

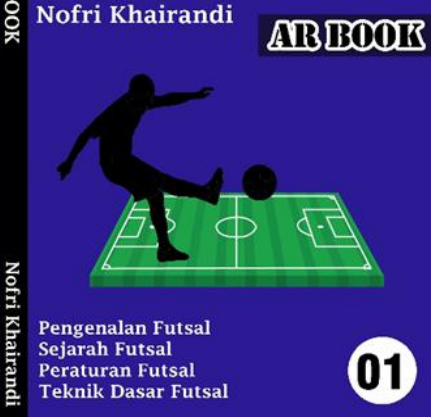

Gambar 9 ARBook Futsal

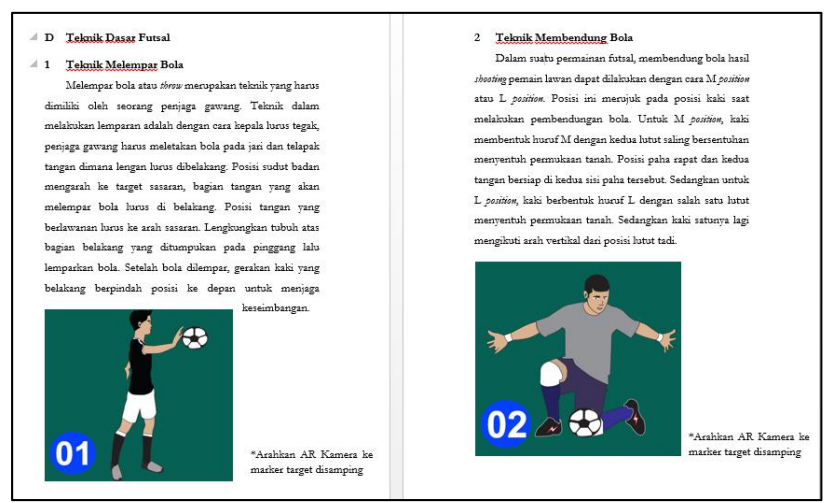

Gambar 8 Isi Buku ArBook 


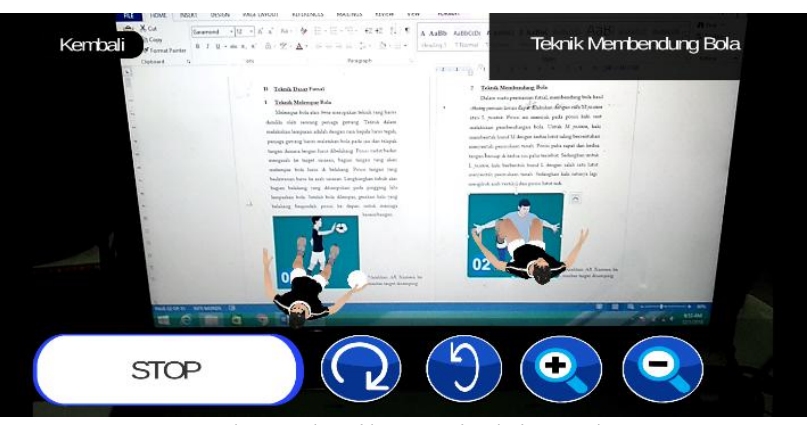

Gambar 9 hasil Memindai Marker

\section{Hasil Pengujian}

Pengujian Aplikasi Pembelajaran Teknik Dasar Futsal Menggunakan Augmented Reality Berbasis Android menggunakan alpha dan beta testing.

1. Pengujian Alpha

Pengujian alpha Aplikasi Pembelajaran Teknik Dasar Futsal 3D AR dilakukan menggunakan blackbox yang akan diuji berdasarkan fungsionalitas sistem yang berjalan pada aplikasi. Berikut hasil tabel pengujian Alpha Aplikasi Pembelajaran Teknik Dasar Futsal 3D AR.

Tabel 1. Hasil Uji Menu Utama

\begin{tabular}{|c|c|c|}
\hline Masukan & HASIL DI HARAPKAN & $\begin{array}{c}\text { Hasil } \\
\text { Pengujian }\end{array}$ \\
\hline $\begin{array}{l}\text { Klik Tombol } \\
\text { AR Kamera }\end{array}$ & $\begin{array}{l}\text { Menampilkan dan } \\
\text { membuka tampilan } \\
\text { AR Kamera }\end{array}$ & Benar \\
\hline $\begin{array}{l}\text { Klik Tombol } \\
\text { Futsal }\end{array}$ & $\begin{array}{lr}\text { Menampilkan } & \text { dan } \\
\text { Membuka } & \text { Materi } \\
\text { Futsal } & \end{array}$ & Benar \\
\hline $\begin{array}{l}\text { Klik Tombol } \\
\text { Bantuan }\end{array}$ & $\begin{array}{l}\text { Menampilkan dan } \\
\text { membuka tata cara } \\
\text { penggunaan aplikasi }\end{array}$ & Benar \\
\hline $\begin{array}{l}\text { Klik Tombol } \\
\text { Tentang }\end{array}$ & $\begin{array}{l}\text { Menampilkan dan } \\
\text { membuka Informasi } \\
\text { aplikasi dan pembuat }\end{array}$ & Benar \\
\hline $\begin{array}{l}\text { Klik Tombol } \\
\text { Keluar }\end{array}$ & Keluar Apikasi & Benar \\
\hline
\end{tabular}

Pengujian selanjutnya adalah mengujikan AR Kamera apakah dapat berjalan dengan benar.

Tabel 2. Hasil Uji AR Kamera

\begin{tabular}{llc}
\hline \multicolumn{1}{c}{ Masukan } & HASIL DI HARAPKAN & $\begin{array}{c}\text { Hasil } \\
\text { Pengujian }\end{array}$ \\
\hline $\begin{array}{l}\text { Klik Tombol } \\
\text { Play/Stop }\end{array}$ & $\begin{array}{l}\text { Memainkan animasi } \\
\text { atau memberhentikan } \\
\text { animasi Teknik dasar }\end{array}$ & Benar \\
& $\begin{array}{l}\text { Futsal } \\
\text { Kemutar Objek 3D }\end{array}$ & Benar \\
$\begin{array}{l}\text { Klik Tombol } \\
\text { Rotasi } \\
\text { horizontal }\end{array}$ & secara Horizontal & \\
$\begin{array}{l}\text { Klik Tombol } \\
\text { Rotaasi } \\
\text { vertikal }\end{array}$ & $\begin{array}{l}\text { Memutar Objrk 3D } \\
\text { secara Vertikal }\end{array}$ & Benar \\
\end{tabular}

Klik Tombol Memperbesar Objek Benar

Zoom In 3D

Klik Tombol Memperkecil Objek Benar

Zoom Out 3D

Klik Tombol Kembali ke Menu Benar

Kembali Utama

Tracking Kamera menampilkan Benar

Image Objek yang benar

Kemudian dilakukan pengujian dalam melacak gambar $3 \mathrm{~d}$ yang tepat kepada Marker yang sudah ada.

Tabel 3. Hasil Uji Tracking Image Target

\begin{tabular}{|c|c|c|}
\hline Masukan & HASIL DI HARAPKAN & $\begin{array}{c}\text { Hasil } \\
\text { Pengujian }\end{array}$ \\
\hline $\begin{array}{l}\text { Gambar } \\
\text { marker } 01\end{array}$ & $\begin{array}{l}\text { Menampilkan objek } \\
\text { 3D animasi Teknik } \\
\text { Melempar Bola }\end{array}$ & Benar \\
\hline $\begin{array}{l}\text { Gambar } \\
\text { marker } 02\end{array}$ & $\begin{array}{l}\text { Menampilkan objek } \\
\text { 3D animasi Teknik } \\
\text { Membendung Bola }\end{array}$ & Benar \\
\hline $\begin{array}{l}\text { Gambar } \\
\text { marker } 03\end{array}$ & $\begin{array}{l}\text { Menampilkan objek } \\
\text { 3D animasi Teknik } \\
\text { Shooting }\end{array}$ & Benar \\
\hline $\begin{array}{l}\text { Gambar } \\
\text { marker } 04\end{array}$ & $\begin{array}{l}\text { Menampilkan objek } \\
\text { 3D animasi Teknik } \\
\text { Passing }\end{array}$ & Benar \\
\hline $\begin{array}{l}\text { Gambar } \\
\text { marker } 05\end{array}$ & $\begin{array}{l}\text { Menampilkan objek } \\
\text { 3D animasi Teknik } \\
\text { Control }\end{array}$ & Benar \\
\hline $\begin{array}{l}\text { Gambar } \\
\text { marker } 06\end{array}$ & $\begin{array}{lr}\text { Menampilkan } & \text { objek } \\
\text { 3D } & \text { animasi } \\
\text { Tendangan } & \text { dengan } \\
\text { Ujung Kaki } & \end{array}$ & Benar \\
\hline $\begin{array}{l}\text { Gambar } \\
\text { marker } 07\end{array}$ & $\begin{array}{l}\text { Menampilkan objek } \\
\text { 3D animasi Teknik } \\
\text { Chipping }\end{array}$ & Benar \\
\hline $\begin{array}{l}\text { Gambar } \\
\text { marker } 08\end{array}$ & $\begin{array}{l}\text { Menampilkan objek } \\
\text { 3D animasi Teknik } \\
\text { Heading }\end{array}$ & Benar \\
\hline $\begin{array}{l}\text { Gambar } \\
\text { marker } 09\end{array}$ & $\begin{array}{l}\text { Menampilkan objek } \\
\text { 3D animasi Teknik } \\
\text { Dribling }\end{array}$ & Benar \\
\hline
\end{tabular}

\section{Pengujian Beta}

Pengujian Beta Aplikasi Pembelajran Teknik Dasar Futsal 3D AR dilakukan menggunakan Quesioner yang akan diuji berdasarkan persepsi kegunaan, kemudahan, konten animasi, dan ketertarikan menggunakan aplikasi yang dirinci menjadi beberapa indikator yaitu mempercepat pekerjaan, meningkatkan kinerja, meningkatkan produktivitas, efektifitas, mempermudah pekerjaan, bermanfaat, mudah dipelajari, dapat dikontrol, jelas dan dapat dipahami, fleksibel, mudah untuk menjadi terampil, mudah digunakan, menyelesaikan pekerjaan, sesegera mungkin, rencana penggunaan, penggunaan dimasa depan, rencana penggunaan berkelanjutan, penggunaan berlanjut, konten animasi, frekuensi 
penggunaan, sesuai waktu minimum, kepuasan, dan rekomendasi. Pengujian ini ditujukan kepada pengguna yaitu Pemain Futsal yang bertujuan mencari informasi mengenai manfaat dalam mempelajari Teknik Dasar Futsal. Berikut hasil pengujian Beta Aplikasi Teknik Dasar Futsal AR 3D.

Tabel 4. Tanggapan Responden Berdasarkan Presepsi

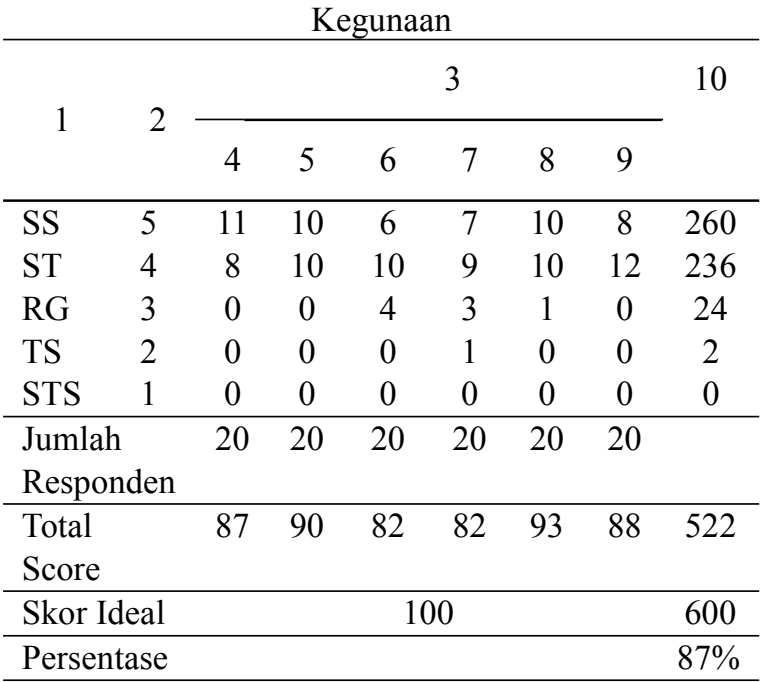

1=Kriteria Jawaban; 2=Bobot; 3=Persepsi Kegunaan; 4=Mempercepat Pekerjaan; 5=Meningkatkan Kinerja; 6=Meningkatkan produktivitas; 7=Efektifitas;

8=Mempermudah Pekerjaan; 9=Bermanfaat; 10=Total;

Setelah melakukan perhitungan skor pada kegunaan diperoleh nilai variabel sebesar $=522$. Perhitungan persentase skor aktual berdasarkan tabel data tanggapan responden berdasarkan persepsi kegunaan, yaitu:

Persentase penerimaan $=\frac{\text { Total } \text { Score }}{\text { skor ideal }} \times 100 \%$

$$
\begin{aligned}
& =\frac{522}{600} \times 100 \% \\
& =87 \%
\end{aligned}
$$

Dari data tanggapan responden berdasarkan persepsi kegunaan, total skor aktual sebesar 522, sedangkan range skor ideal sangat setuju yaitu 600, sehingga dapat dikatakan bahwa $87 \%$ responden setuju bahwa Aplikasi Pembelajaran Teknik Dasar Futsal AR 3D memiliki kegunaan atau bermanfaat. Secara grafis persentase kriteria kegunaan digambarkan melalui pie chart seperti tampak pada Gambar 10.

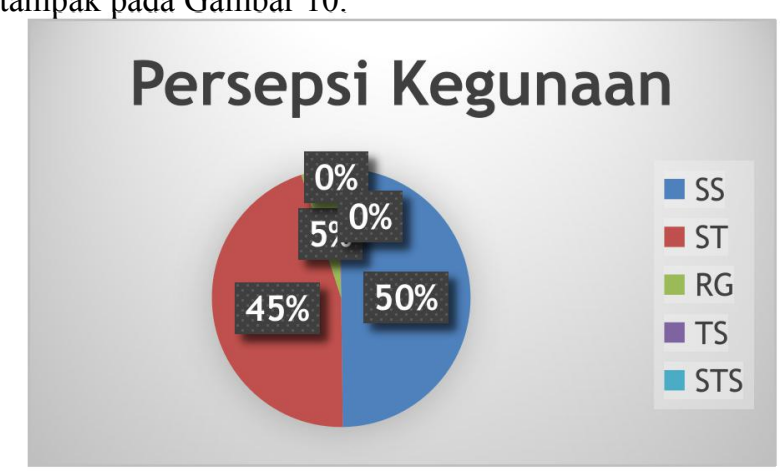

Gambar 10 Pie Chart Kegunaan

Hasil tanggapan reponden berdasarkan persepsi kemudahan pengoprasian aplikasi dapat dilihat pada Tabel 5.

Tabel 5. Tanggapan Responden Berdasarkan Presepsi

\begin{tabular}{|c|c|c|c|c|c|c|c|c|}
\hline \multirow{2}{*}{1} & \multirow{2}{*}{2} & \multicolumn{6}{|c|}{3} & \multirow[t]{2}{*}{10} \\
\hline & & 4 & 5 & 6 & 7 & 8 & 9 & \\
\hline SS & 5 & 9 & 5 & 7 & 6 & 7 & 10 & 220 \\
\hline ST & 4 & 9 & 11 & 11 & 11 & 10 & 8 & 240 \\
\hline $\mathrm{RG}$ & 3 & 1 & 4 & 2 & 3 & 3 & 2 & 45 \\
\hline TS & 2 & 1 & 0 & 0 & 1 & 0 & 0 & 2 \\
\hline STS & 1 & 0 & 0 & 0 & 0 & 0 & 0 & 0 \\
\hline \multicolumn{2}{|c|}{$\begin{array}{l}\text { Jumlah } \\
\text { Responden }\end{array}$} & 20 & 20 & 20 & 20 & 20 & 20 & \\
\hline \multicolumn{2}{|c|}{$\begin{array}{l}\text { Total } \\
\text { Score }\end{array}$} & 86 & 81 & 85 & 83 & 84 & 88 & 507 \\
\hline \multicolumn{2}{|c|}{ Skor Ideal } & & & \multirow{2}{*}{\multicolumn{2}{|c|}{100}} & & & 600 \\
\hline Persen & tase & & & & & & & $85 \%$ \\
\hline
\end{tabular}
Pengoperasian Aplikasi

$1=$ =riteria Jawaban; 2=Bobot; $3=$ Persepsi Pengoperasian Aplikasi; 4=Mudah dipelajari; 5=Mudah dikendalikan; 6=Mudah dipahami; 7=Fleksibel; 8=mudah terampil; 9=Mudah digunakan; $10=$ Total;

Setelah melakukan perhitungan skor pada kemudahan pengoprasian aplikasi diperoleh nilai variabel sebesar $=$ 507. Perhitungan persentase skor aktual berdasarkan tabel data tanggapan responden berdasarkan persepsi kemudahan pengoprasian aplikasi, yaitu:

Persentase penerimaan $=\frac{\text { Total Score }}{\text { skor ideal }} \times 100 \%$

$$
\begin{aligned}
& =\frac{507}{600} \times 100 \% \\
& =85 \%
\end{aligned}
$$

Dari data tanggapan responden berdasarkan persepsi kemudahan pengoprasian aplikasi, total skor aktual sebesar 507, sedangkan range skor ideal sangat setuju yaitu 600, sehingga dapat dikatakan bahwa $85 \%$ responden setuju bahwa Aplikasi Pembelajaran Teknik Dasar Futsal AR 3D mudah untuk digunakan. Secara grafis persentase kriteria kemudahan pengoprasian aplikasi digambarkan melalui pie chart seperti tampak pada Gambar 11. 


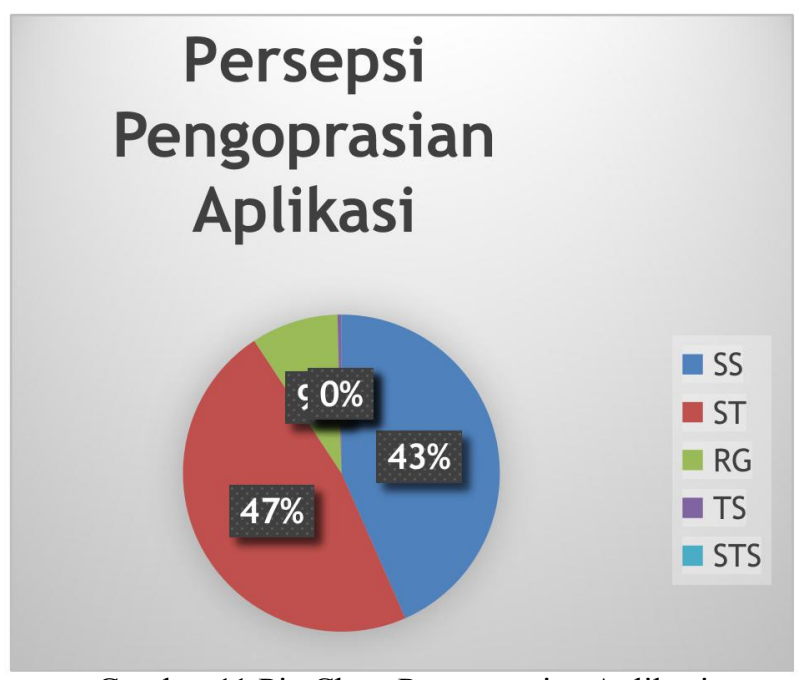

Gambar 11 Pie Chart Pengoprasian Aplikasi

Hasil tanggapan reponden berdasarkan persepsi konten animasi aplikasi dapat dilihat pada Tabel 6.

Tabel 6. Tanggapan Responden Berdasarkan Presepsi Konten Animasi

\begin{tabular}{|c|c|c|c|c|c|c|c|}
\hline \multirow{2}{*}{1} & \multirow{2}{*}{2} & \multicolumn{5}{|c|}{3} & \multirow{2}{*}{9} \\
\hline & & 4 & 5 & 6 & 7 & 8 & \\
\hline SS & 5 & 13 & 9 & 7 & 7 & 5 & 205 \\
\hline ST & 4 & 6 & 11 & 10 & 11 & 13 & 204 \\
\hline $\mathrm{RG}$ & 3 & 1 & 0 & 3 & 2 & 2 & 24 \\
\hline TS & 2 & 0 & 0 & 0 & 0 & 0 & 0 \\
\hline STS & 1 & 0 & 0 & 0 & 0 & 0 & 0 \\
\hline $\begin{array}{l}\text { Jumlah } \\
\text { Responden }\end{array}$ & & 20 & 20 & 20 & 20 & 20 & \\
\hline Skor Aktual & & 92 & 89 & 84 & 83 & 83 & 433 \\
\hline Skor Ideal & & & & & & & 500 \\
\hline Presentase & & & & & & & $87 \%$ \\
\hline
\end{tabular}

1=Kriteria Jawaban; 2=Bobot; 3=Konten Animasi; 4=Sesuai Animasi; 5=Benar dan jelas; $6=\mathrm{SOP} ; 7=$ Tempo irama; 8=HItungan; 9=Total;

Setelah melakukan perhitungan skor pada konten animasi aplikasi diperoleh nilai variabel sebesar $=433$.

Perhitungan persentase skor aktual berdasarkan tabel data tanggapan responden berdasarkan persepsi konten animasi aplikasi, yaitu:

Persentase penerimaan $=\frac{\text { Total Score }}{\text { skor ideal }} \times 100 \%$

$$
\begin{aligned}
& =\frac{433}{500} \times 100 \% \\
= & 87 \%
\end{aligned}
$$

Dari data tanggapan responden berdasarkan persepsi konten animasi aplikasi, total skor aktual sebesar 433, sedangkan range skor ideal sangat setuju yaitu 600, sehingga dapat dikatakan bahwa $87 \%$ responden setuju bahwa Aplikasi Pembelajaran Teknik Dasar Futsal AR 3D sesuai dengan konten animasi yang disajikan.

Secara grafis persentase kriteria konten animasi aplikasi digambarkan melalui pie chart seperti tampak pada Gambar 12.

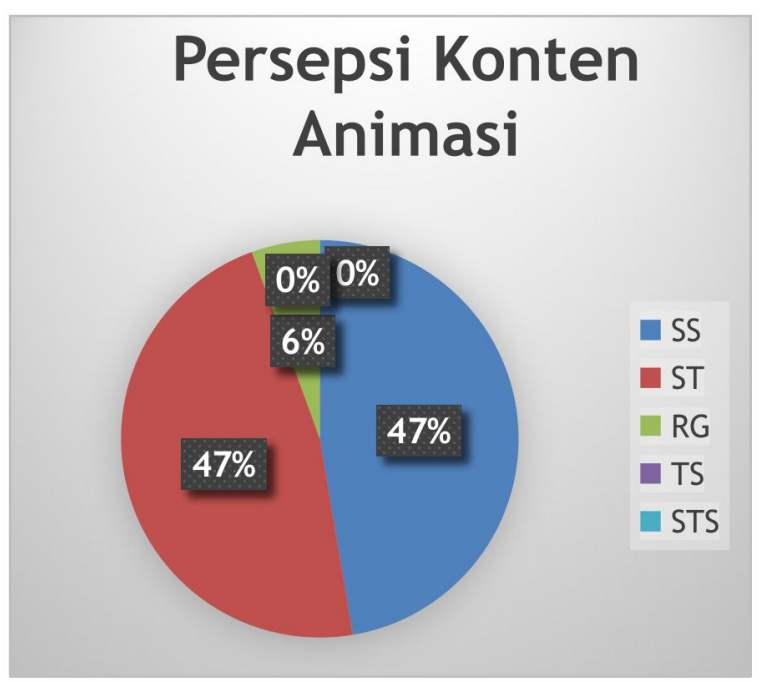

Gambar 12 Pie Chart Konten Animasi

Hasil tanggapan reponden berdasarkan persepsi ketertarikan penggunaan aplikasi dapat dilihat pada Tabel 7.

Tabel 7. Tanggapan Responden Berdasarkan Presepsi Kegunaan

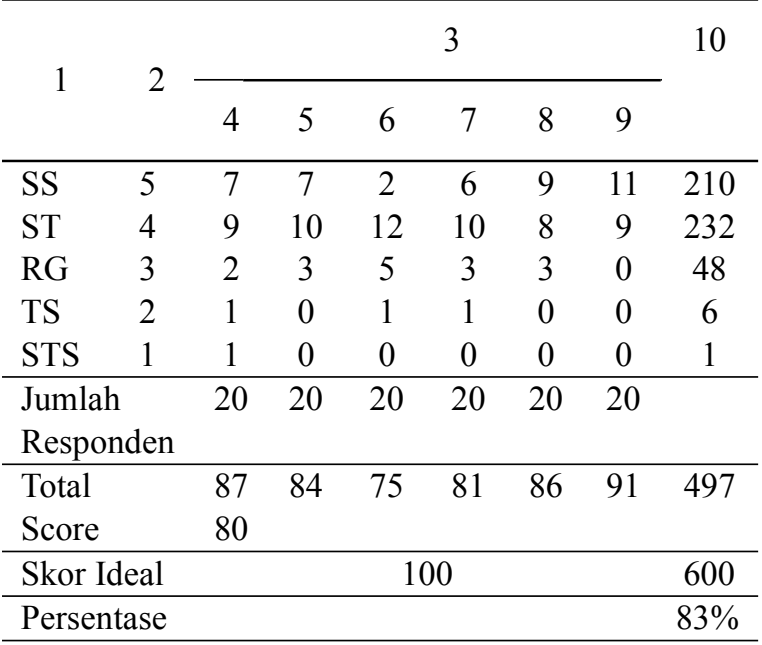

1=Kriteria Jawaban; 2=Bobot; 3=Ketertarikan;

4=Penggunaan Sesungguhnya; 5=Intensitas; 6=Frekuensi Penggunaan; 7=Sesuai Waktu Minimum; 8=Kepuasan; 9=Rekomendasi; 10=Total;

Setelah melakukan perhitungan skor pada ketertarikan pengguna aplikasi diperoleh nilai variabel sebesar $=497$.

Perhitungan persentase skor aktual berdasarkan tabel data tanggapan responden berdasarkan persepsi ketertarikan pengguna aplikasi, yaitu:

Persentase penerimaan $=\frac{\text { Total Score }}{\text { skor ideal }} \times 100 \%$

$$
\begin{aligned}
& =\frac{497}{600} \times 100 \% \\
& =83 \%
\end{aligned}
$$

Dari data tanggapan responden berdasarkan persepsi 
ketertarikan pengguna aplikasi, total skor aktual sebesar 497, sedangkan range skor ideal sangat setuju yaitu 600, sehingga dapat dikatakan bahwa $83 \%$ responden tertarik menggunakan Aplikasi Pembelajaran Teknik Dasar Futsal AR 3D.

Secara grafis persentase kriteria ketertarikan pengguna aplikasi digambarkan melalui pie chart seperti tampak pada Gambar 13 .

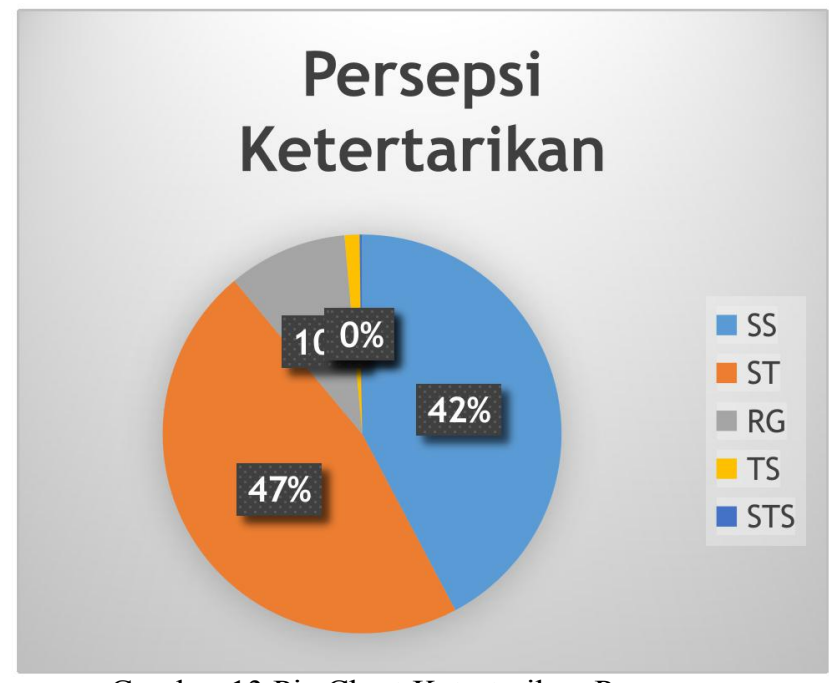

Gambar 13 Pie Chart Ketertarikan Pengguna

\section{Kesimpulan}

Kesimpulan dari penelitian mengenai Aplikasi Pembelajaran "Teknik Dasar Futsal" Berbasis Android adalah sebagai berikut:

1. Aplikasi Pembelajaran "Teknik Dasar Futsal" Berbasis Android merupakan aplikasi pembelajaran berbasis android yang digunakan sebagai media pembelajaran teknik dasar futsal dengan simulasi 3D yang dapat digunakan pada perangkat mobile berbasis android tanpa perlu koneksi internet. Adapun pembuatan program menggunakan IDE Unity yang merupakan aplikasi pemrograman yang dapat digunakan untuk pembuatan program berbasis desktop maupun mobile, dengan memanfaatkan vuforia sebagai asset plugin untuk membuat aplikasi augmented reality dengan objek 3D manusia yang didapatkan dari proses pemodelan menggunakan aplikasi makehuman dan memanfaatkan aplikasi blender untuk membuat animasi dan desain objek 3D. Aplikasi Pembelajaran Teknik Dasar Futsal AR 3D yang dibuat berisi informasi mengenai teknik dasar futsal dalam bentuk animasi 3D, sehingga pengguna dapat menerima informasi dalam bentuk visualisasi digital teknik dasar futsal dan pengguna dapat berinterasi dengan objek 3D tersebut.

2. Aplikasi Pembelajaran "Teknik Dasar Futsal" Berbasis Android memiliki teori dan terdapat simulasi 3D dari "Teknik Dasar Futsal" sebagai peraga dari teori yang dimiliki dengan memindai marker yang telah tersedia

\section{Daftar Pustaka}

Journal Article

[1] Mulyono, M. A., 2017. Buku Pintar Futsal. Jakarta: Anugrah.

[2] Muhammad, F., Nugroho, R. A. \& N, D. T., 2016. Analisis User Experience Untuk Tingkat Keterpilihan Smartphone Android. Jurnal Ilmu Komputer, Volume 4.

[3] Agustina, C. \& Wahyudi, T., 2015. Aplikasi Game Pendidikan Berbasis Android. Indonesian Journal on Software Engineering, Volume 1. Monograph, edited book, book.

[4] Henrysson, A., 2007. Bringing Augmented Reality to Mobile Phones.

[5] Saputro, R. E. \& Saputra, D. I. S., 2014. Pengembangan Media Pembelajaran Mengenal Organ Pencernaan Manusia Menggunakan Teknologi Augmented Reality. EJournal, Volume 6.

[6] Ardiyansyah, F., 2014. Implementasi Pattern Recognition Pada Pengenalan Monumen-Monumen Bersejarah Di Kota Bandung Menggunakan Augmented Reality Berbasis Android. Komputer dan Informatika, Volume 01-08.

[7] Mukti, I. S. A., Lumenta, A. S. M. \& Sugiarso, B. A., 2016. Rancang Bangun Aplikasi Pembelajaran Untuk Anak Umur 6 - 9 Tahun Berbasis Android. E-Journal Teknik Informatika, Volume 7, p. 1.

[8] Diartono, D. A., 2008. Media Pembelajaran Desain Grafis Menggunakan Photoshop Berbasis Multimedia. Jurnal Teknologi Informasi DINAMIK, Volume 13, p. 3.

[9] Riady, S. C., Sentinuwo, S. \& Karouw, S., 2016. Rancang Bangun Aplikasi Mobile Learning Anak Sekolah Minggu dengan Teknologi Augmented Reality Berbasis Android. Teknik Informatika, Volume 9, p. 1.

[10] Arifitama, B., 2017. Panduan Mudah Membuat Augmented Reality. Yogyakarta:

[11] Sujati, D. A., Isnanto, R. R. \& Martono, K. T., 2016. Pengembangan Aplikasi Multimedia Untuk Pembelajaran Satelit Astronomi Nasa Dengan Teknologi Augmented Reality Berbasis Android. Teknologi dan Sistem Komputer, Volume 4, p. 2.

[12] Hidayat, T., 2015. Penerapan Teknologi Augmented Reality Sebagai Model Media Edukasi Kesehatan Gigi Bagi Anak. Citec Journal, Volume 2, p. 1.

[13] Pradipta, I. G. A. B. H. A., Darmawiguna, I. G. M. \& Pradnyana, G. A., 2017. Pengembangan Aplikasi Augmented Reality Markerless Pengenalan Dan Teknik Dasar Bola Basket. Mahasiswa Pendidikan Teknik Informatika, Volume 6, p. 3.

[14] Andi.Kusrianto, A., 2005. Panduan Lengkap Memakai Adobe Photoshop CS. s.1.:Elex Media Komputindo.

[15] Hidayat, A. \& Mujahiduddien, A., 2017. Pembelajaran Bentuk Sendi Tulang Manusia Menggunakan Konsep Augmented Reality. Siliwangi, Volume 3, p. 1.

[16] Sutopo, A. H., 2003. Multimedia Interaktif dengan Flash. Yogyakarta: Graha Ilmu. 